\title{
Purple-Flowered Moss Phlox
}

\author{
Arch. C. Budd (Swift Current)
}

In reference to the purple flowered Moss Phlox mentioned in the last Blue Jay, this form is fairly common in the area from Swift Current south. The most striking and deepest purple patch we have seen is right on No. 4 highway, but many smaller and paler clumps have been found. I do not know if the colour is permantly purple or mauve as some patches I found, photographed and marked this spring were white flowered when I visited them a week later. We have sometimes found that Moss Phlox will flower in the fall.

Many of our native plants show great variation in colour. On one knoll at Eastend one spring we found Smooth Blue Beard-tongue (Pentstemon nitidus) in all inter-shades from its normal deep blue, through purple, red and pink to pure white. White Spiderflowers (Cl eome serrulata) instead of pink are quite common, and often a white flowered Wild Bergamot (Monarda) can be found. The pink Shooting-star (Dodecatheon) frequently has a white form as does the all too common Canada Thistle.

Patience - (continued from page 2)

merely talking to them. Presently I could move closer. This took weeks of of winter patience, but once they got used to my presence close at hand, progress was much quicker. One day, 1 sat down and put my hand, peanut laden, where the tray had been. Sweetheart cussed, and hesitated, flitting back and forth in disgust. But finally she took the plunge, and lit on my finger. Her dismay, when she felt soft flesh instead of unyielding twig, was comical. Literally, she nearly fell off backwards, but did hold on.

I kept my hand utterly still; though I was bursting to shout with exultation, I only wheedled her with my usual "tzick-a-dee-ing". Suddenly she leaned forward, grabbed a bit of nut, and fled. I dashed indoors to proclaim my success.

In but a few days Sweetheart would light on my hand with little hesitation, except to look the situation over with beady black eyes as chickadees al ways do. Soon she would come, outdoors, to a peanut tied to my hat and then to my hand as I stood by the clothesline or under a tree. Finally to my supreme triumph and exquisite delight, one day she lit on a peanut held between my lips and pried the nut out of the opened half, shifting so her claws clenched on my lip, and with her tail tight propped against my chin. Once she, ran up my face to search for other nuts on my hat leaving the tingle of pleasure that she trusted me to linger when she flew away. Only when I wore a fur collar would she refuse to come to my face.

Her mate reluctantly came to by hand for food, but never to my lips. The following winter, the smallest of their current bird also learned to feed from my hand, and I wonder now if it is the one who reninds me so of my vanished pet.

For al as, Sweetheart's foolhardiness must have been her undoing. A year ago she, as usual, called to me when she returned; and darted down to the promptly proffered peanut. Summer wariness would not at once give way to remembere d trust of ine . . . but I never had another chance to tempt her.

(continued on page 19) 